\title{
WATER TEMPERATURE INFLUENCE ON SELECTED PROPERTIES OF SURFACE RIVER WATER THROUGHOUT THE YEAR (RIVER NITRA)
}

\author{
VIERA VANKOVÁ, PETER PETLUŠ
}

Department of Ecology and Environmental Sciences, Fakulty of Natural Sciences, Constantiene the Philosopher University, Nitra, Tr. A Hlinku 1, 94974 Nitra, Slovak Republic; e-mail: vvankova@ukf.sk, ppetlus@ukf.sk

\begin{abstract}
Vanková V., Petluš P.: Water temperature influence on selected properties of surface river water throughout the year (river Nitra). Ekológia (Bratislava), Vol. 33, No. 2, p. 151-159, 2014.

Assessment of chosen surface water properties was realised as a part of broader research on environmental aspects of urban environment. Analyses of selected physical and chemical water properties, oxygen and temperature regime, neutralisation capacity, selected nutrients and measurements of air temperature was done in monthly intervals during 2012 at three localities. Two of the assessed localities are at river Nitra: Nitra Communal Services and housing estate Chrenová I. The third locality is the oxbow lake of Malá Hangócka river at Nitra City Park. We have assessed the volume of oxygen concentration $\left(\mathrm{O}_{2}, \mathrm{mg} / \mathrm{l}\right)$ and oxygen regime, phosphates $\left(\mathrm{P}_{-} \mathrm{PO}_{4}^{-3}, \mathrm{mg} / \mathrm{l}\right)$, ammoniac nitrogen $\left(\mathrm{N}-\mathrm{NH}_{4}{ }^{+}, \mathrm{mg} / \mathrm{l}\right)$, nitrites $\left(\mathrm{N}-\mathrm{NO}_{2}{ }^{-}, \mathrm{mg} / \mathrm{l}\right), \mathrm{pH}$ and water temperature $\left({ }^{\circ} \mathrm{C}\right)$ from the collected samples. Out of these analyses the values of the above mentioned indicators, their annual fluctuation and water quality of observed localities were obtained. The influence of human activities on water properties and its quality was further assessed. Statistical methods such as two-factor dispersion analysis without replication and correlation coefficient were applied to validate the correlation of selected surface water properties, water and air temperature and to compare observed localities.
\end{abstract}

Key words: water properties, water quality, Nitra River, two-factor dispersion analysis without replication and correlation coefficient.

\section{Introduction}

Basic principles of water quality assessment are described by Langhammer $(2002,2005)$ and Langhammer et al. (2012). They distinguished two approaches: analytical and holistic. Physical and chemical water properties are assessed by the former approach and bio indicators by the latter. Pitter (1999) claims that the aim of the analytical water quality analyses is to set the level of concentration of selected elements in the water for a chosen locality at selected time. There are more authors who are engaged in the assessment of water properties and water quality issues, e.g. Grmela and Kopp (2012), Sulvová et al. (2009), Váňová and Langhammer (2011). Assessment of water properties and classification of surface water bodies is based on the Slovak Government bid number 269/2010 adapted to European Union standards. The bid sets standards for good state of waters. Langhammer (2002) and Pitter (1999) refer to relation between physicochemical water properties and current variability of individual parameters of running and still waters. 
The aim of the study is to find out the values of individual surface water quality parameters influenced by developing urban environment and its validation by using statistical analyses.

\section{Material and methods}

Values of individual physical and physicochemical parameters were assessed monthly from January to December 2012 for the water samples from three different localities on river Nitra. The volume of oxygen $\left(\mathrm{O}_{2}, \mathrm{mg} / \mathrm{l}\right)$ - oxygen regime, phosphates $\left(\mathrm{P}_{-} \mathrm{PO}_{4}^{-3}, \mathrm{mg} / \mathrm{l}\right)$, ammoniac nitrogen $\left(\mathrm{N}_{-} \mathrm{NH}_{4}^{+}, \mathrm{mg} / \mathrm{l}\right)$, nitrites $\left(\mathrm{N}_{-} \mathrm{NO}_{2}{ }^{-}, \mathrm{mg} / \mathrm{l}\right), \mathrm{pH}$ and water temperature $\left({ }^{\circ} \mathrm{C}\right)$ were analysed from the collected samples. Multicomponent portable Aeroqual AQM60 Environmental Station with incorporated weather transmitter WXT520 Vaisala was used to measure air temperature. Air temperature was observed at the same localities as the water samples (Pucherová et al., 2013).

\section{Observed localities}

The surface water analyses conducted in monthly intervals were done at three localities at river Nitra: Nitra Communal Services and housing estate Chrenová I. The third locality was the oxbow lake of Malá Hangócka River at Nitra City Park. The Nitra river is one of the most polluted rivers in Slovakia because there are many contaminants at a relatively short stretch of the river.

Nitra Communal Services (NCS) - sample locality lies on the left bank of Nitra river at an unpopulated part of the city. The grassy river bank without trees and shrubs is regularly mown. A number of intensively cultivated allotments and NCS Company are located nearby.

Housing estate Chrenová I (CHRENOVÁ I) - sample locality lies on the left bank of Nitra river under the Chrenovsky bridge. The river bank is stabilised with concrete and stones. The water flows slowly here and water birds are present throughout the year. Housing estate Chrenová I lies on its left side. The parallel pavement lined with trees is utilised for recreation and sport activities.

Nitra City Park (PARK) - sample locality lies at the oxbow lake of Malá Hangócka in Nitra City Park. This oxbow lake emerged as a result of cutting off one branch of Nitra river, which is nowadays used for fishing. The river banks are not maintained, they are occasionally grassy with bushes and trees. The river bed is muddy.

\section{Methods of selected water properties assessment}

The samples of surface water were taken $10-20 \mathrm{~cm}$ below the water surface and $30 \mathrm{~cm}$ from the river bank. Immediately after the sample was taken the water temperature was measured. The analyses were done directly at the spot using a compact portable laboratory. After found the above limit values further analyses were carried out in laboratory using spectrophotometer with different wavelengths ranging from 419 to $700 \mathrm{~mm}$ and 1-5 cm length of cuvette (Mullin, Riley, 1955).

The volume of phosphates was assessed by method of setting the soluble inorganic orthophosphates. Volume of oxygen was assessed by titration. Ammoniac was assessed by Nessler's reagent. The volume of nitrates was assessed by diazotisation of sulfanilic acid and the nitrates present in the sample. Recommended methods of surface water assessment are described in Slovak Government bid number 269/2010.

Individual correlations were assessed by a number of statistical methods. Two-factor dispersion analysis without replication was used to observe the influence of two factors on the importance value of the observed indicators, while $p$ was our determination value. The tested parameter is not depending on the locality if $p$ is greater than 0.05 and vice versa. Pears-Bravais correlation coefficient was used to assess the relation between statistical attributes and the strength of their correlation (Markechová et al., 2011). The entire test was done in STATISTIKA program. We have also set the water quality level based on measured values at each locality.

\section{Results and discussion}

The observed annual trends of water temperature influenced by air temperature were based on measured values. As Langhammer (2002) states that the temperature cycle is influenced by direct solar radiation followed by water heating. He also states that absolute value range of 
river water temperature can be from $0{ }^{\circ} \mathrm{C}$ to over $30^{\circ} \mathrm{C}$. We have observed the range of water temperature during 2012 from $1^{\circ} \mathrm{C}$ to $27^{\circ} \mathrm{C}$ at the observed localities NCS and CHRENOVÁ I and from $1{ }^{\circ} \mathrm{C}$ to $26^{\circ} \mathrm{C}$ at PARK (Table 1). The lowest water temperatures were measured at CHRENOVÁ I locality (Fig. 1). The water temperature at NCS was $3-4{ }^{\circ} \mathrm{C}$ higher compared to other localities in the months of January and February, which was most probably caused by the fact the NCS is the only locality directly exposed to direct sunlight. In spite of the low air temperatures the water surface got warmer faster. Gradually the water temperature became similar and the differences were lower.

T a b le 1. Air and water temperature as measured at observed localities in 2012.

\begin{tabular}{|l|c|c|c|c|c|c|}
\hline & \multicolumn{9}{|c|}{ Locality } \\
\hline Month & $\begin{array}{c}\text { Air } \\
\text { temperature } \\
\left({ }^{\circ} \mathrm{C}\right)\end{array}$ & $\begin{array}{c}\text { Water } \\
\text { temperature } \\
\left({ }^{\circ} \mathrm{C}\right)\end{array}$ & $\begin{array}{c}\text { Cir } \\
\text { temperature } \\
\left({ }^{\circ} \mathrm{C}\right)\end{array}$ & $\begin{array}{c}\text { Water } \\
\text { temperature } \\
\left({ }^{\circ} \mathrm{C}\right)\end{array}$ & $\begin{array}{c}\text { Air } \\
\text { temperature } \\
\left({ }^{\circ} \mathrm{C}\right)\end{array}$ & $\begin{array}{c}\text { Water } \\
\text { temperature } \\
\left({ }^{\circ} \mathrm{C}\right)\end{array}$ \\
\hline JAN & 3.2 & 4 & 4.8 & 1 & 2.5 & 1 \\
\hline FEB & -6.5 & 5 & -7.2 & 1 & 1.3 & 1 \\
\hline MAR & 7.8 & 9 & 14.8 & 10 & 13 & 11 \\
\hline APR & 10.2 & 11.5 & 13.5 & 14.5 & 10.8 & 12 \\
\hline MAY & 13.5 & 17 & 14 & 16 & 13.9 & 17 \\
\hline JUN & 25.6 & 24 & 26 & 24 & 29.5 & $\mathbf{2 6}$ \\
\hline JUL & 27 & $\mathbf{2 7}$ & 27.2 & $\mathbf{2 7}$ & 22.5 & 25 \\
\hline AUG & 26.8 & 25 & 27.9 & 25 & 30.5 & $\mathbf{2 6}$ \\
\hline SEP & 15 & 18 & 19.9 & 16 & 17.4 & 19 \\
\hline OCT & 13.5 & 12 & 15.1 & 15 & 14.6 & 13 \\
\hline NOV & 9.5 & 14 & 9.3 & 9 & 10.3 & 13 \\
\hline DEC & 1.1 & 1 & -2.9 & 1 & 2.4 & 1 \\
\hline
\end{tabular}

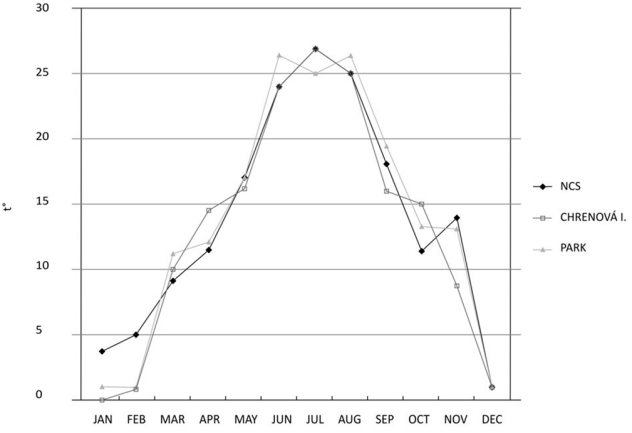

Fig. 1. Surface water temperature at observed localities in 2012.

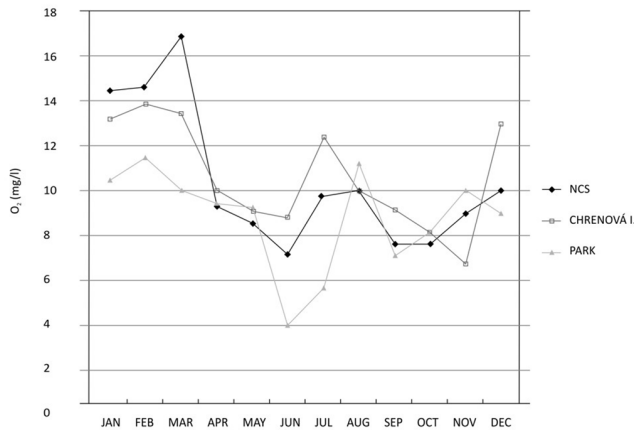

Fig. 2. Annual oxygene regime of surface river waters at observed localities in 2012.

Any other surface water temperature differences among the localities on river Nitra were determined by the fact that the NCS is characterised by slow steady stream flow and waters are not mixed at the same pace as at CHRENOVÁ I. For qualitative aspects of the river, the water temperature is an important factor affecting the oxygen regime, biochemical processes but also for aquatic and semiaquatic organisms. In terms of temperature, the observed waters were mostly in class I quality during the year. The waters reached $22.5-30.5^{\circ} \mathrm{C}$ in summer months (June, July, August) and when over $25^{\circ} \mathrm{C}$ the water quality reached the class III quality 
at all observed localities. The hypothesis that the water temperature increases with raising air temperature and it has a direct influence on the water quality was proved.

The relation between air and water temperature was statistically validated based on calculated $r$ coefficient among observed attributes and the intensity of the statistical dependency was set. Correlation coefficient was calculated for each locality separately. The coefficient value was 0.947344 at NCS, 0.966425 at PARK and 0.948297 at CHRENOVÁ I. The relation between air and water temperature was verified as the $r$ coefficient value was higher than 0.9 at all observed localities means that there is very high dependency among chosen indicators: increasing air temperature is accompanied by increasing water temperature and decreasing air temperature is accompanied by decreasing water temperature unless the water temperature gets to $0{ }^{\circ} \mathrm{C}$.

Annual oxygen regime showed certain differences in some months. The differences in measured oxygen concentrations occurred mainly between cold winter months and warm summer months, while the lower oxygen concentrations were observed in summer (Fig. 2). It is obvious that the amount of oxygen dissolved in water is dependent on water temperature. Maidment (1993) presents that the level of oxygen concentration can change remarkably depending on water temperature. Up to $4 \mathrm{mg} / \mathrm{l}$ of oxygen dissolved in water can occur within the range from 5 to $20^{\circ} \mathrm{C}$. This relation was verified within observed localities. The differences in oxygen concentrations between warm and cold season at NCS, CHRENOVÁ I and PARK were 9.9, 7.3 and $7.6 \mathrm{mg} / \mathrm{l}$, respectively (Table 2). The lowest values of oxygen concentration at CHRENOVÁ I could be caused by the lowest water temperature regime. Pitter (2009) shows that water temperature has fundamental influence on dissolved oxygen concentration in water. The same was verified at the observed localities. Significant changes in oxygen regime can be,

T a b l e 2. Oxygen regime of surface waters measured at observed localities in 2012.

\begin{tabular}{|l|c|c|c|}
\hline & \multicolumn{3}{|c|}{ Locality } \\
\hline Month & NCS & CHRENOVÁ I & PARK \\
\hline JAN & \multicolumn{3}{|c|}{$\mathrm{O}_{2}(\mathrm{mg} / \mathrm{l})$} \\
\hline FEB & 14.5 & 13.2 & 10.5 \\
\hline MAR & 14.7 & $\mathbf{1 3 . 9}$ & $\mathbf{1 1 . 5}$ \\
\hline APR & $\mathbf{1 7}$ & 13.5 & 10 \\
\hline MAY & 9.2 & 10 & 9.3 \\
\hline JUN & 8.5 & 9 & 9.2 \\
\hline JUL & $\mathbf{7 . 1}$ & 8.7 & 3.9 \\
\hline AUG & 9.7 & 12.5 & $\mathbf{5 . 5}$ \\
\hline SEP & 10 & 10 & 6.9 \\
\hline OCT & 7.5 & 9.1 & 8.1 \\
\hline NOV & 7.5 & 8 & 10 \\
\hline DEC & 8.9 & $\mathbf{6 . 6}$ & 8.9 \\
\hline
\end{tabular}

according to Langhammer (2002), caused by heat and water pollution but this was not verified at the localities. The differences among the localities were observed in March and July. The oxygen regime has significantly changed in spite of low temperature differences. It can be assumed that the changes were caused by significant and sudden increase of air temperature. The first warming occurred during spring season (February and March) when the air temperature increased by $12.6{ }^{\circ} \mathrm{C}$ in average. In June and May the air temperature increased $13.2^{\circ} \mathrm{C}$. Both periods showed changed oxygen regime, which continued in warm July. 
The oxygen regime during the observed period can be evaluated as very good because most of the measured values were in class I water quality level. The worse water quality of all observed localities was measured in the oxbow lake of Malá Hangócka (in September class II and in June and July class III). The reason is that the oxygen regime of still waters usually lower compared to flowing waters (Table 2). The results were confirmed based on statistical assessment and two-factor dispersion analysis without replication (Fig. 3). The assessment was done based on calculated $p$ values of probability. The $p$ value was 0.034320 , which means the oxygen regime statistically depends on sample locality. Our evaluation shows comparable oxygen regime at NCS and CHRENOVÁ I while at PARK the values are lower because it is a still water. The oxygen concentration also depends on the character of the water body and seasons.

The phosphates showed little fluctuations over time (Table 3). The values at NCS and CHRENOVÁ I ranged from 0 to $0.5 \mathrm{mg} / \mathrm{l}$. At PARK from 0 to $0.25 \mathrm{mg} / \mathrm{l}$ (Fig. 4). The volume of phosphates was stable throughout the year. The influence of water temperature on phosphates concentration in the water during the warmer summer months was not significant. Differences were observed when comparing localities. Mainly NCS and CHRENOVÁ I showed higher concentrations of phosphates compare to PARK - oxbow of Malá Hangócka. The highest values were measured at CHRENOVÁ I. The differences between the still and running waters could be due to the fact that the Nitra River flows through Nitra town and intensively cultivated agricultural land. The phosphates could be washed into the river waters from the agricultural land where artificial fertilisers are applied. Tůma (2000) shows that phosphates are mostly absorbed by the surface layer of the soils or in the unsaturated zone. It enters the surface waters directly

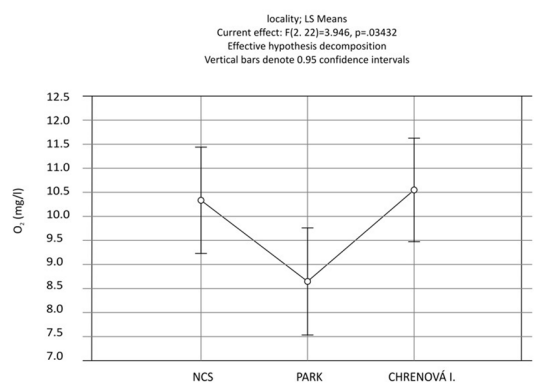

Fig. 3. Average values of oxygen regime measured at observed localities in 2012 .

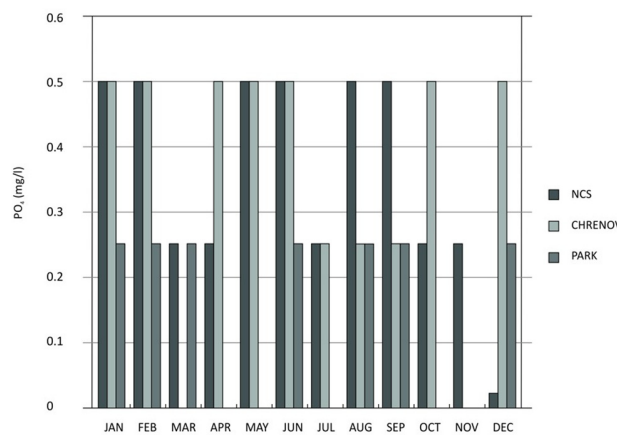

Fig. 4. Annual flow of phosphates in surface waters at observed localities in 2012.

through surface runoff and soil erosion. The oxbow lake Malá Hangócka is not in contact with agricultural land therefore lower levels of phosphates in its waters are expected.

Water quality of class III appeared most often during the water quality assessment. It means that the water is polluted and has insignificant landscape-building value and is suitable only for industrial supplies. The highest values of phosphate concentrations during the year were observed at CHRENOVÁ I.

The statistical analyses showed the value of $p$ is 0.001084 , which means that the volumes of phosphates in water at observed localities are statistically significant. The lowest values were 
T a b l e 3. Phosphate levels in surface water as measured at observed localities in 2012.

\begin{tabular}{|l|c|c|c|}
\hline & \multicolumn{3}{|c|}{ Locality } \\
\hline Month & NCS & CHRENOVÁ I & PARK \\
\hline & \multicolumn{3}{|c|}{$\left(\mathrm{PO}_{4}^{-3}, \mathrm{mg} / \mathrm{l}\right)$} \\
\hline JAN & 0.5 & 0.5 & 0.25 \\
\hline FEB & 0.5 & 0.5 & 0.25 \\
\hline MAR & 0.25 & 0 & 0.25 \\
\hline APR & 0.25 & 0.5 & 0 \\
\hline MAY & 0.5 & 0.5 & 0 \\
\hline JUN & 0.5 & 0.5 & 0.25 \\
\hline JUL & 0.25 & 0.25 & 0.25 \\
\hline AUG & 0.5 & 0.25 & 0.25 \\
\hline SEP & 0.5 & 0.25 & 0 \\
\hline OCT & 0.25 & 0.5 & 0 \\
\hline NOV & 0.25 & 0 & 0.25 \\
\hline DEC & 0.025 & 0.5 & \\
\hline
\end{tabular}

T a b l e 4. Volume of ammoniac, nitrites and $\mathrm{pH}$ at observed localities in 2012.

\begin{tabular}{|l|c|c|c|c|c|c|c|c|c|}
\hline & \multicolumn{9}{|c|}{ Locality } \\
\hline Month & $\mathrm{pH}$ & $\begin{array}{c}\mathrm{NH}_{4}+ \\
(\mathrm{mg} / \mathrm{l})\end{array}$ & $\begin{array}{c}\mathrm{NO}_{2} \\
(\mathrm{mg} / \mathrm{l})\end{array}$ & $\mathrm{pH}$ & $\begin{array}{c}\mathrm{NH}_{4}+ \\
(\mathrm{mg} / \mathrm{l})\end{array}$ & $\begin{array}{c}\mathrm{NO}_{2} \\
(\mathrm{mg} / \mathrm{l})\end{array}$ & $\mathrm{pH}$ & $\begin{array}{c}\mathrm{NH}_{4}+ \\
\left(\mathrm{mg}^{\prime}\right)\end{array}$ & $\begin{array}{c}\mathrm{NO}_{2} \\
(\mathrm{mg} / \mathrm{l})\end{array}$ \\
\hline JAN & 7.5 & 0.2 & 0.025 & 7.5 & 0.2 & 0.025 & 7.5 & 0.2 & 0.025 \\
\hline FEB & 8 & 0.2 & 0.025 & 7.5 & 0.2 & 0.025 & 7.5 & 0.2 & 0.025 \\
\hline MAR & 8 & 0.2 & 0.025 & 7.5 & 0.2 & 0.025 & 8 & 0 & 0.075 \\
\hline APR & 7.5 & 0.2 & 0.025 & 8 & 0.2 & 0.1 & 7.5 & 0 & 0.025 \\
\hline MAY & 7.5 & 0.2 & 0.15 & 8 & 0 & 0.4 & 8 & 0 & 0 \\
\hline JUN & 7.5 & 0.2 & 0.15 & 8 & 0.1 & 0.2 & 7.5 & 0.4 & 0.025 \\
\hline JUL & 8 & 0.2 & 0.2 & 8 & 0.2 & 0.2 & 7.5 & 0 & 0 \\
\hline AUG & 6.5 & 0.2 & 0.05 & 8 & 0.2 & 0.05 & 8 & 0.2 & 0 \\
\hline SEP & 7.5 & 0.2 & 0.1 & 7.5 & 0.2 & 0.1 & 7.5 & 0.2 & 0 \\
\hline OCT & 7.5 & 0 & 0.075 & 7.5 & 0.2 & 0.075 & 8 & 0 & 0.05 \\
\hline NOV & 7.5 & 0.2 & 0.075 & 7.5 & 0.2 & 0.025 & 7.5 & 0.2 & 0.05 \\
\hline DEC & 7.5 & 0.2 & 0.05 & 7.5 & 0.4 & 0.075 & 7.5 & 0.2 & 0.025 \\
\hline
\end{tabular}

measured at PARK (Fig. 5). In spite of this the water quality at Malá Hangócka was low (III. class) similar to other observed localities.

The presence of nitrogen compounds with focus on ammoniac and nitrites were also assessed. All observed values of ammoniac, nitrites and $\mathrm{pH}$ are shown in Table 4. Grünvald (1997) presents that ammoniac can be present in two forms depending on the $\mathrm{pH}$ of water: dissociated form $\mathrm{NH}_{4}^{+}$and non-dissociated form $\mathrm{NH}_{3}$.

Based on the obtained $\mathrm{pH}$ values it is evident that ammoniac was present at observed localities in dissociated form. According to Grünvald (1997) dissociated form of ammoniac is present in water between 96 and $100 \%$ if $\mathrm{pH}$ values oscillate in the range between 6 and 8 , which can be considered positive in regard to water quality. Dissociated form is harmless in high concentrations while non-dissociated form is toxic to aquatic life. Grünvald (1997) and Langhammer (2002) present that ammoniac is usually present in low concentrations in natural waters. It is usually 0.2 to $1 \mathrm{mg} / \mathrm{l}$ in surface waters. The limits observed at our localities were comparable except two occasions - CHRENOVÁ I in December and PARK in June (Fig. 6), where the level of ammoniac was $0.4 \mathrm{mg} / \mathrm{l}$. These increased values appeared most likely due to application of agricultural fertilisers during spring and due to post-harvest soil in autumn. But Pitter (1999) states that ammoniac is present in all surface water bodies whether polluted 


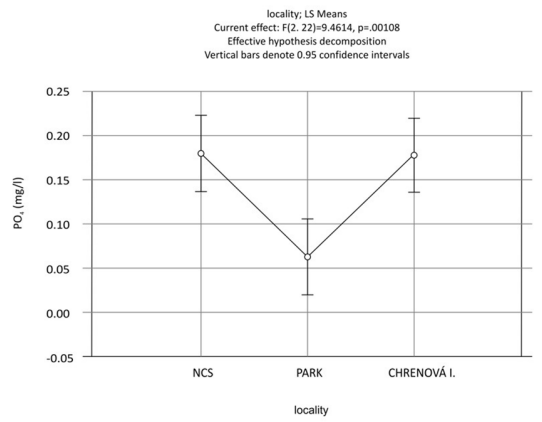

Fig. 5. The average values of phosphates measured at observed localities in 2012.

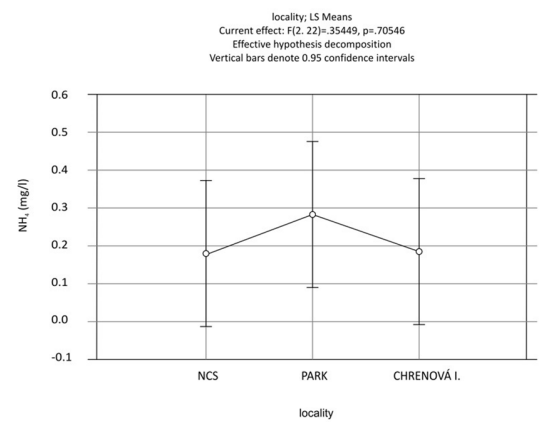

Fig. 7. Average ammoniac values obtained from observed localities in 2012.

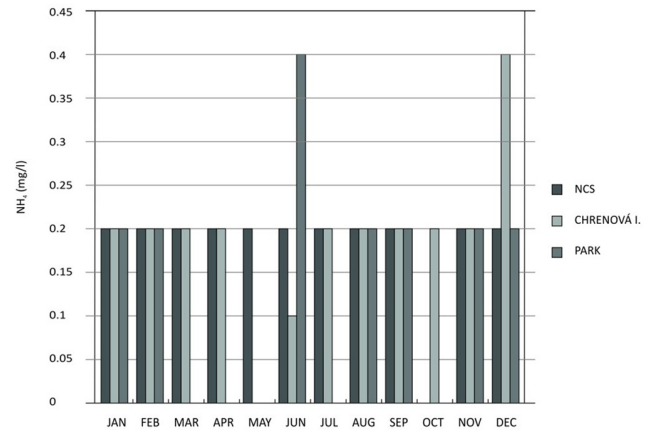

Fig. 6. Annual cycle of ammoniac in surface waters at each locality in 2012.

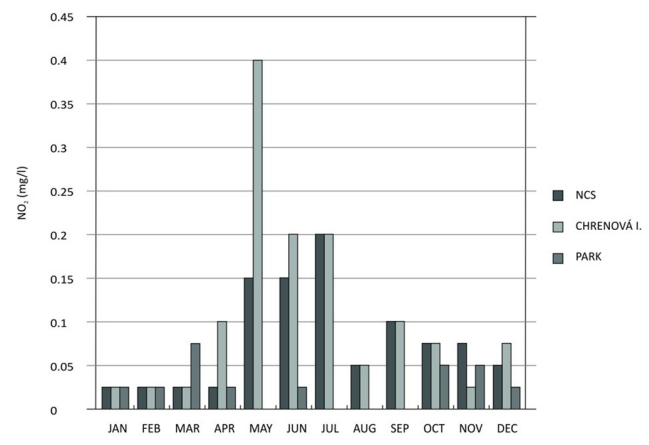

Fig. 8. Annual cycle of nitrites in surface waters at observed localities in 2012.

or not. The obtained values are also influenced by its instability, nitrification and their changes from nitrites to nitrates.

According to statistical analyses of obtained values, PARK is the most affected by ammoniac. The $p$ value was 0.509101 (Fig. 7). This was expected because there is still water at the PARK locality compare to running water at the rest of the observed localities. Langhammer (2002) shows that the bigger the stream flow the smaller the volume of ammoniac in the water. This relation is very significant at places with very strong focal pollution that had not been identified during the monitoring.

The class I water quality was observed in regard to the level of ammoniac in the waters except the two cases when ammoniac was $0.4 \mathrm{mg} / \mathrm{l}$, which is attributed to class II quality.

The levels of nitrites showed slight differences during the observed year (Table 4). The level of nitrites at NCS ranged from 0.025 to $0.2 \mathrm{mg} / \mathrm{l}$, at CHRENOVÁ I from 0.025 to 0.4 $\mathrm{mg} / \mathrm{l}$ and at PARK from 0 to $0.025 \mathrm{mg} / \mathrm{l}$ (Fig. 8). The lowest values at PARK can be attributed due to the fact that during the measurements the nitrites were present in form of ammoniac nitrogen. The highest values were found at CHRENOVÁ I with the maximum in May. Pitter (1999) mentions that nitrites are practically absent in natural surface water bodies. It can 


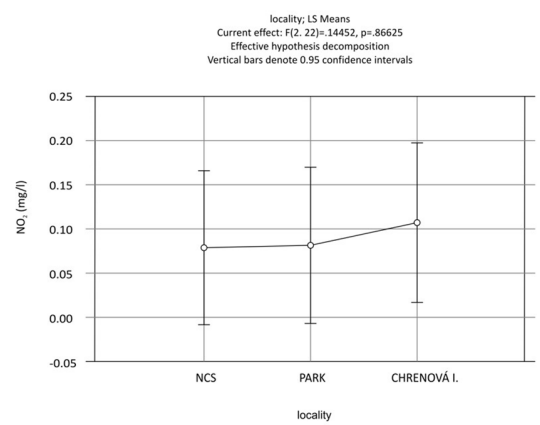

Fig. 9. Average values of nitrites in surface waters at observed localities in 2012.

be assumed that the waters at our localities were polluted by application of chemical fertilisers at the intensively cultivated agricultural land. The obtained values were also verified statistically.

The statistical validation has proven that the highest level of nitrites was at CHRENOVÁ I. The value $p$ reached 0.866254 (Fig. 9). This was not the case at NCS, which could be caused by lack of stability of the nitrogen compounds. NCS lies after CHRENOVÁ I so the form of the compounds could be changed downstream.

The levels of nitrites did not fit into the best water quality class at observed localities. The water quality ranged from class II to IV at CHRENOVÁ I and from class II to V at NCS (the STN 757221 government bid for nitrites only states 'quality requirements met' or 'quality requirements not met'). The water quality requirements were not met in May 2012, which could act as toxic for aquatic organisms (Langhammer, 2002). It can be assumed that the unfavourable water quality in May could be caused by warming, which normally influences the biomass production in water. The other cause could be agricultural fertilisers used at the upper stream of river Nitra. At PARK the nitrites met the water quality requirements only in May, July, August and September 2012 (class I of water quality). In the remaining year the water quality dropped to class II. The temperature differences between summer and winter season did not influence the levels of evaluated nutrients in the waters.

\section{Conclusion}

The quality and state of surface waters at chosen localities at Nitra River and oxbow lake Malá Hangócka was observed and analysed based on chemical analyses. The water sample analyses were conducted for chosen groups of water quality indicators: oxygen regime, basic physiochemical attributes $(\mathrm{pH}$, water temperature), nutrients (ammoniac nitrogen, nitrites, phosphates). The assessments were based on the assumption that water properties change in monthly intervals during the year but also depend on locality and temperature.

The assumption was verified for the relation between water temperature and oxygen regime. It is evident that if the oxygen regime is low the water is polluted and of low quality. Phosphates were present at each observed locality with the lowest values at PARK, which can be attributed to PARK's location. PARK is not in direct contact with intensively cultivated agricultural land.

The levels of ammoniac were highest at PARK, which verified the assumption that the levels of ammoniac are higher in still waters without the influence of stream flow. The highest levels of nitrites were confirmed at CHRENOVÁ I, mainly during spring season, which can be attributed to human agricultural activities around the area. The influence of temperature on the level of nutrients was not recorded during the observed period. 
The obtained results were verified statistically. The aim of the statistical analyses was to find out and verify the relations between individual water properties, the influence of human pollution, water and air temperature and comparisons to observed localities.

The water quality fluctuated in the range from class I to III quality. Overall water quality of Nitra River and Malá Hangócka oxbow lake is in class III (the average state of the water). However this cannot be presented as standard, because out of all recommended indicators only chosen groups were assessed and among them only chosen indicators. The selection of indicators was adapted to the options of terrain survey followed by analyses. The Nitra river as well as Malá Hangócka oxbow lake show long-term anthropic water pollution. The surface water pollution was verified based on annual observations of selected attributes. In spite of reduced human activities with negative impact, the trend of water pollution at river Nitra is not receding. The pollution affects the changes of water properties. This long-term water pollution in Nitra city can act as a negative factor for the waters' land use potential. The results can be used for evaluation of hygienic quality of the waters in urban environment. Significant changes in levels of observed indicators were observed during the summer season. It is recommended to conduct water quality assessment mainly during summer season and observe the chosen properties closely on daily bases.

These results are part of a complex research focused on assessment of environmental aspects of urban environment and it is realised.

\section{Acknowledgements}

Thanks to the support of operational program Research and development for project: Environmental aspects of urban environment (code ITMS 26220220110) and is co-financed by European Fund for Regional Development.

\section{References}

Grmela, J. \& Kopp R. (2012) (on line). Monitoring of a potential pollution sources of the river Svratka (in Czech). (cit. 2013-06-24) http://mnet.mendelu.cz/mendelnet2012/articles/34_grmela_720.pdf

Grünvald, A. (1997). Hydrochemistry (in Czech). Praha: ČVUT.

Langhammer, J. (2002). The quality and protection of surface water (in Czech). Praha: PF UK.

Langhammer, J. (2005). Classification of the dynamics of water quality changes in the Elbe River basin. Journal of Hydrology and Hydromechanics, 53(4), 205-218.

Langhammer, J., Hartvich, F., Mattas, D., Rödlová, S. \& Zbořil A. (2012). The variability of surface water quality indicators in relation to watercourse typology, Czech Republic. Environ. Monit. Assess., 184, 3983-3999. DOI: 10.1007/s10661-011-2238-9.

Maidment, D.R. (1993). GIS and hydrologic modelling. In M.F. Goodchild, B.O. Parks \& L.T. Steyaert (Eds.), Environmental modeling with GIS (pp. 147-167). New York: Oxford University Press.

Markechová, D., Tirpáková, A. \& Stehlíková B. (2011). General statistics for the educationists (in Slovak). Nitra: FPV UKF.

Mullin, J.B. \& Riley J.P. (1955). The spectrophotometric determination of nitrate in natural waters, with particular reference to sea-water. Anal. Chim. Acta, 12, 464-480. DOI: 10.1016/S0003-2670(00)87865-4.

Pitter, P. (2009). Hydrochemistry (in Czech). Praha: VŠCHT.

Pucherová, Z., Tirpáková, A., Markechová, D. \& Rózová Z. (2013). Use of statistical methods in the evaluation of CO and $\mathrm{SO}_{2}$ in the air quality monitoring (in Slovak). Forum Statisticum Slovacum, 9(3), 89-97.

STN 757221 (1999). The quality of surface water. The classification of surface water (in Slovak).

Šulvová, L., Ženišová, Z., Ďuričková, A. \& Flaková R. (2009). The oxygen regime of gravel pits water in the area of Bratislava (in Slovak). Acta Geologica Slovaca, 1(2), 93-102.

Tůma, A. (2000). The water quality in the Nové Mlýny reservoir (in Czech). Brno: Povodí Moravy.

Váňová, V. \& Langhammer J. (2011). Modelling the impact of land cover changes on flood mitigation in the upper lužnice basin. Journal of Hydrology and Hydromechanics, 59, 262-274. 